\title{
DIATESIS (TAI) DALAM BAHASA JEPANG (TINJAUAN DALAM BUKU MINNA NO NIHONGO)
}

\author{
Parwati Hadi Noorsanti \\ Universitas Airlangga, santi_parwati@yahoo.com
}

\begin{abstract}
Diathesis is a grammatical category that shows the relationship between the participant or the subject with the action expressed by the verb in the clause. In the book Minna no Nihongo I and II there are several types of sentences containing diathesis. This type of diathesis is often quite difficult for a Japanese learner. In this theoretical study paper the author describes the meaning of diathesis sentences contained in Minna no Nihongo I and Minna no NihongoII books used in basic and intermediate Japanese language learning. With this paper is expected to increase the understanding of learners of Japanese diathesis sentences. The types of diathesis sentences analyzed are judoutai (passive diathesis), Shieki (causative), kanoutai (potential form) and jujuhyougen (giving and receiving phrases). In addition to understanding the structure of diathesis, some things that the learner needs to understand, among others, in the passive diagrams sentence (vocabulary) verbs or actions centered on objects not actors, in causative sentences (Shieki), verbs that can be used as a causative form are verbs States the type of meaning of action or change (active verb), in understanding the form of sentence jujuhyougen, the learner must understand that in the sentence using jujuhyougen expression contained the meaning of gratitude or gratitude because the offender or subject sentence gets the good of others.
\end{abstract}

Keywords: diatesis, Minna no Nihongo, judoutai, shieki, kanoutai, juju hyougen

\begin{abstract}
ABSTRAK
Diatesis merupakan kategori gramatikal yang menunjukkan hubungan antara partisipan atau subjek dengan perbuatan yang dinyatakan oleh verba dalam klausa. Dalam buku Minna no Nihongo I dan II terdapat beberapa jenis kalimat yang mengandung diatesis. Jenis kalimat diatesis ini sering kali dirasakan cukup sulit bagi pembelajar bahasa Jepang. Dalam makalah yang bersifat kajian teoritis ini penulis mendeskripsikan makna kalimat-kalimat diatesis yang terdapat dalam buku Minna no Nihongo I dan Minna no NihongoII yang digunakan dalam pembelajaran bahasa Jepang tingkat dasar dan menengah. Dengan tulisan ini diharapkan akan menambah pemahaman pembelajar terhadap kalimat diatesis bahasa Jepang. Jenis-jenis kalimat diatesis yang dianalisis yaitu judoutai (diatesis
\end{abstract}


pasif), Shieki (kausatif), kanoutai (bentuk potensial) dan jujuhyougen (ungkapan memberi dan menerima). Selain memahami struktur kalimat diatesis, beberapa hal yang perlu dipahami oleh pembelajar antara lain, dalam kalimat diatesis pasif (judoutai) verba kalimat atau perbuatan terpusat pada objek bukan pelaku perbuatan, dalam kalimat kausatif (Shieki), verba yang dapat dijadikan bentuk kausatif adalah verba yang menyatakan tipe makna tindakan atau perubahan (verba aktif), dalam memahami bentuk kalimat jujuhyougen, pembelajar harus memahami bahwa di dalam kalimat yang menggunakan ungkapan jujuhyougen terkandung makna terima kasih atau rasa syukur karena pelaku atau subjek kalimat mendapat kebaikan dari orang lain.

Kata kunci: diatesis, Minna no Nihongo, judoutai, shieki, kanoutai, juju hyougen

\section{PENDAHULUAN}

Penggolongan satuan bahasa berdasarkan pada bentuk, fungsi, dan makna disebut kategori gramatikal (bunpo kategorii). Kategori gramatikal pada predikat kalimat verbal dalam bahasa Jepang biasanya mencakup: tingkat kehalusan (teineisa), bentuk positif dan negatif (mitomekata), voice atau diatesis (tai), aspek (sou), kala atau tense (jisei), dan modalitas (hou) (Sutedi, 2008: 76). Diatesis sering disebut juga dengan voice. Menurut Lyon (1995: 364 )

"Istilah voice (kata latinnya vox) mula-mula dipakai oleh ahli-ahli tabahasa Romawi dalam dua arti yang berbeda, tetapi berhubungan: i. Dalam arti "bunyi" (yang dipakai dalam lafal bahasa manusia dengan menerjemahkan istilah Yunani phone)"terutama bunyi-bunyi yang dihasilkan oleh getaran"vocal cords", pita suara: dari inilah jadinya istilah "vokal"(dari kata Latinsonus vocalis, "asound produced with voice", via kata Perancis kuno vouel), ii. dalam arti "bentuk" kata (yaitu, seperti apa "bunyi" nya yang beroposisi dengan "makna"-nya.

Menurut Verhaar (2010: 130), diatesis adalah bentuk verba transitif yang subjeknya sedemikian rupa sehingga dapat atau tidak dapat berperan ajentif. Diatesis dibedakan sebagai "aktif" dan "pasif" dan dalam bahasa tertentu juga sebagai "medial"

56 | http://journal.unesa.ac.id/index.php/paramasastra 
Menurut Kridalaksana (2001: 43), diatesis merupakan kategori gramatikal yang menunjukkan hubungan antara partisipan atau subjek dengan perbuatan yang dinyatakan oleh verba dalam klausa, ada diatesis aktif, pasif dan sebagainya.

Diatesis aktif (active voice) merupakan bentuk gramatikal sebuah dan/atau klausa, yang subjek gramatikalnya merupakan pelaku; lawan dari diatesis pasif. Diatesis medial (middle voice) merupakan diatesis yang menunjukkan pelaku berbuat untuk dirinya sendiri. Diatesis pasif (passive voice) merupkan diatesis yang menunjukkan bahwa subjek adalah tujuan dari perbuatan, misalnya 'Ia dipukul'. Diatesis reflektif (reflexice voice) diatesis yang menunjukkan subjek berbuat atas dirinya sendiri, misalnya 'Ia bercukur'. Diatesis resiprokal (reciprocal voice) diatesis yang menunjukkan subjek pluralis bertindak berbalasan atau subjek singularis bertindak berbalasan dengan komplemen, misalnya 'Mereka berpukul-pukulan' atau 'Ia berpukul-pukulan dengan temannya.'

Menurut Chaer (2007: 265) diatesis adalah gambaran hubungan antarapelaku atau peserta dalam kalimat dengan perbuatan yang dikemukakan dalam kalimat itu. Ada beberapa macam diatesis, antara lain, (1) diatesis aktif, yakni jika subjek yang berbuat atau melakukan suatu perbuatan, contoh 'Mereka merampas uang kami'; (2) diatesis pasif, jika subjek menjadi sasaran perbuatan, contoh 'Uang kami dirampasnya'; (3) diatesis refleksif, yakni jika subjek berbuat atau melakukan sesuatu terhadap dirinya sendiri, contoh, 'Nenek kami sedang berhias'; (4) diatesis resiprokal, yakni jika subjek yang terdiri dari dua pihak berbuat tindakan berbalasan, contoh 'Kiranya mereka akan berdamai juga'; dan (5) diatesis kausatif, yakni jika subjek menjadi penyebab atas terjadinya sesuatu, contoh 'Kakek menghitamkan rambutnya.'

Dalam bahasa Jepang, diatesis disebut tai (態) atau boisu (voice). Menurut Shirakawa (2002: 186) ヴォイスとは、簡単に言えば、ある出来事を様々な参加者の立場から表現 
する方法の集まりです (Boisu to wa, kantan ni ieba, aru dekigoto o samazamana sankasha no tachibakara hyougen suru houhou no atsumari desu) "Voice secara sederhana adalah kumpulan cara mengungkapkan suatu kejadian dari berbagai macam posisi partisipan”.

Menurut Muraki dalam (Sutedi, 2008: 78), diatesis dalam bahasa Jepang mencakup; kalimat pasif (judoubun/受動文), kalimat kausatif ( shiekibun/使役文)， kalimat transitif (tadoushibun/他動詞文)， intransitif ( jidoushibun/＼cjkstart自動詩文)， kalimat resiprokal (sougobun/ 相互文)、kalimat refleksif ( saikibun/ 再帰文) , kalimat yang menyatakan abilitas ( kanoubun/ 可能文), keinginan ( kiboubun/ 希望文), spontanitas ( jihatsubun/ 自発文), kalimat yang menyatakan aksi memberi dan menerima ( jujubun/ 授受文), kalimat yang menyatakan bentuk te aru ( te arubun/てある文 )

Lebih lanjut Shirakawa (2002: 186) mengatakan bahwa posisi partisipan yang menggambarkan kejadian terbagi menjadi dua, yaitu partisipan yang berperan langsung dalam kejadian seperti pada kalimat pasif langsung (chokusetsu ukemibun/直接受身文) dan kalimat resiprokal (sougobun/ 相互文)dan partisipan yang berperan secara tidak langsung dalam kejadian seperti pada kalimat kausatif (shiekibun/ 使役文) dan kalimat pasif tidak langsung (kansetsu ukemibun/ 間接受身文)

Pada tulisan ini hanya akan dibahas pada kalimat pasif, kausatif, kalimat potensial, dan kalimat verba memberi dan menerima.

58 | http://journal.unesa.ac.id/index.php/paramasastra 


\section{PEMBAHASAN}

\section{Kalimat Pasif (Judou bun/受動文)}

Dalam bahasa Jepang kalimat pasif disebut ukemi atau jodoubun. Menurut Tsujimura (2000: 233) kalimat pasif dalam bahasa Jepang terdiri atas: direct passive (pasif langsung), indirect passive (pasif tidak langsung) dan ni yottepassive (kalimat pasif dengan partikel ni yotte).

\section{Pasif Langsung/ Direct Pasif (chokusetsu ukemibun/ 直接受身文 )}

Menurut Miyajima (2003: 216) mengenai tipe kalimat pasif langsung yaitu,

直接受身文とは対応する能動文の補語の表す人やものを主語として表現す る受身文である(Chokusetsu ukemibun to wa taiousuru noudoubun no hogo no arawasu hito ya mono o shugo toshite hyougen suru ukemibun de aru)。"Kalimat pasif yang terbentuk dari kalimat transitif (aktif) yang subjeknya berupa manusia atau benda ".

Contoh:

1. 子供の時、よく 母に しかられました。

Kodomo no toki, yoku haha ni shikarareta.

(Pada waktu anak-anak, (saya) sering dimarahi ibu)

2.わたしは部長に ほめられました。

Watashi wa buchou ni homeraremashita.

(Saya dipuji kepala bagian) 


\section{3.わたしは部長に 仕事を頼まれました。}

(Watashi wa buchou ni shigoto o tanomaremashita.)

Saya diminta pekerjaan oleh kepala bagian.

Pada kalimat ketiga kalimat tersebut, yang menjadi objek kalimat (objek yang dikenai tindakan atau perkara), terpusat pada watashi 'saya' sedangkan yang menjadi subjek pelaku aktifitas yaitu orang lain, yang dinyatakan dengan partikel 'ni'. Makna kepasifan pada kalimat 1, kalimat 2 dan kalimat 3 dampaknya dapat dirasakan langsung oleh objek kalimat yaitu watashi (saya), kejadian tersebut seperti 'dimarahi'(shikarareta), 'dipuji’ (homeraremashita), dimintai (tanomaremashita)

\section{Pasif tidak Langsung (Kansetsu Ukumeibun/ 間接受身文)}

Kalimat pasif tidak langsung yaitu, objek yang dikenai tindakan atau perkara tidak muncul sebagai objek seperti dalam kalimat aktif dan mengandung makna kerugian, atau tindakan menyusahkan (Soepardjo, 2012: 149). Karena secara umum kalimat pasif tidak langsung banyak digunakan untuk menunjukkan suatu hal yang tidak menyenangkan subjek kalimat, maka kalimat pasif tidak langsung ini sering disebut dengan meiwaku no ukemi(迷惑の受身) atau kalimat pasif yang tidak menyenangkan /menggangu subjek kalimat (Miyajima, 2003: 217). Dalam tipe kalimat pasif tidak langsung ini partisipan berperan secara tidak langsung dalam kejadian.

Contoh:

\section{4. 私は 買い物の途中で雨に降られた。}

Watashi wa kaimono no tochuu de ame ni furareta.

(Saya kehujanan di tengah jalan saat berbelanja) 
Parwati Hadi Noorsanti, Diatesis (TAl) dalam Bahasa Jepang...(hlm. 55 - 71)

\section{5. 佐藤さんは、息子さんに死なれて、大きなショックを受けている。}

Satou san wa, musuko san ni shinarete, ookinaa shokku o ukete iru.

Karena ditinggal mati oleh anak laki-lakinya, Pak Satou mengalami stres yang berat.

Pada kalimat 4 kalimat pasif digunakan untuk mengungkapkan suatu hal yang tidak menyenangkan atau mengandung makna kerugian, dalam hal ini adalah kejadian 'kehujanan'(ame ni furareta). Pada kalimat 5, hal yang tidak menyenangkan yang dialami oleh Pak Satou sebagai pihak yang menderita adalah kejadian 'ditinggal mati oleh anak laki-lakinya ', sehingga untuk menunjukkan suatu hal yang tidak menyenangkan tersebut, predikat kalimat dinyatakan dengan bentuk verba pasif yaitu shinarete/死なれて (ditinggal mati), yang merupakan bentuk pasif dari shinu/死ぬ yang artinya mati/ meninggal.

\section{Kalimat Pasif Posesif (Mochinushi no Ukemi 持ち望の受身文)}

Kalimat pasif posesif adalah kalimat pasif yang subjek tidak langsung dikenai perbuatan, melainkan secara tidak langsung merasakan akibat dari kejadian tersebut. Pada prinsipnya, kalimat pasif tidak langsung hampir sama maknanya dengan kalimat pasif tipe pasif posesif, hanya pembedaan ini dilihat dari ruang lingkup diri pembicara yang dikenai tindakan yang merugikan.

Menurut Miyajima (2003: 218) kalimat pasif posesif adalah kalimat pasif yang objeknya adalah kepemilikan sesuatu atau seseorang yang ditunjukkan dengan partikel $n i$ dan $o$ dalam kalimat transitif (持ち主受身は、対応する能動文のヨ格助詞や二格助詞などの表す人や物 の持ち主を主語として表現する受身文である。Mochinushi ukemi wa, taiou 
suru noudoubun no o kakujoshi ya ni kakujoshi nado no arawasu hito ya mono no mochinushi o shugo toshite hyougen).

Contoh:

6. 田中が佐藤に肩をこづかれた。

Tanaka ga Satou ni kata o kozukareta.

(Pundak Tanaka ditepuk oleh Satou)

\section{7. ラッシュの 電車で 足を踏まれました。}

Rasshu no densha de ashi o fumaremashita.

(Di dalam kereta yang penuh sesak, kaki saya diinjak (oleh seseorang))

Pada saat menggunakan kata kerja yang menyatakan perbuatan atau penemuan seperti menulis (kakimasu/書きます)、 ( hatsumei shimasu/ 発明します)、(hakken shimasu/ 発見します) dalam bentuk pasif, maka pelakunya harus ditunjukkan dengan partikel $\sim$ ni yotte.

Contoh

8.「源氏物語」は紫式部に よって 書かれました。

Genjimonogatari wa Murasaki Shikibu ni yotte kakaremashita.

Hikayat Genji ditulis oleh Murasaki Shikibu

Pada kalimat 8, predikat verba adalah kakaremashita (ditulis), yang merupakan verba yang bersifat suatu penciptaan atau penemuan sehingga pelaku dari penulisan cerita Hikayat Genji yaitu Murasaki Shikibu ditandai dengan partikel $\sim$ ni yotte.

Ungkapan Memberi-Menerima (Juju Hyougen /授受表現)

62 | http://journal.unesa.ac.id/index.php/paramasastra 
Menurut Shirakawa (2002: 160), jujuhyougen atau verba yarimorai adalah verba yang mengungkapkan aktifitas memberi-menerima seperti: yaru, ageru, sashiageru; kureru, kudasaru; morau, itadaku, yang dalam bentuk verba bantu yaitu; te yaru, te ageru, te sashiageru; te kureru, kudasaru; te morau, te itadaku.

Contoh

9. 私は木村さんに花をあげます。

Watashi wa Kimura san ni hana o agemasu.

(Saya memberi Kimura bunga)

\section{0. 私はカリナさんに チョコレートをもらいました。}

Watashi wa Karina san ni chokoreeto o moraimashita.

(Saya menerima coklat dari Kimura)

Pada kalimat 9, pihak yang menjadi benefaktor (pihak yang menerima keuntungan) adalah 'watashi (saya)' yang dalam kalimat ini adalah menerima 'coklat ', sedangkan pihak yang menjadi agentor (pihak yang memberi jasa/ keuntungan) adalah Karina, yaitu orang yang memberi coklat. Sedangkan pada kalimat 10, pihak yang menjadi agentor adalah Karina dalam hal ini Karina memberi coklat kepada 'saya' yang berperan sebagai benefaktor karena telah menerima coklat dari Karina.

Walaupun dalam kalimat 9 dan 10 , subjek kalimat adalah 'watashi', akan tetapi makna kalimat menjadi berbeda karena verba yang digunakan sebagai predikat juga berbeda.

Contoh

11. 佐藤さんは 私に クリスマスカードを くれました。 
Satou san wa watashi ni kurisumasuka-do o kuremashita.

Sato memberi saya kartu natal.

Pada kalimat 11 yang menjadi agentor adalah Satou dan yang menjadi benefaktor adalah watashi saya, makna yang sama apa bila menggunakan predikat moraimashita. Hanya dalam kalimat ini yang berkedudukan sebagai subjek kalimat adalah Sato, dan pada predikat verba moraimashita yang berkedudukan sebagai subjek adalah watashi.

Pada bab 24, bentuk verba juju hyougen yang digunakan adalah hojodoushi 補助動詞, yaitu berbentuk verba bantu. Dalam bentuk hojodoushi, ungkapan jujuhyougen (memberi-menerima) yang digunakan dalam kalimat bukan sebagai verba utama, melainkan hanya menyokong makna dari verba utama. Seperti dalam kalimat 12 perdikat verba dalam kalimat yaitu kashite agemashita (meminjamkan) yang terdiri dari kasu dan ageru yang arti secara leksikal nya 'meminjamkan' dan 'memberi'. Akan tetapi, pada saat verba agemashita berfungsi sebagai verba bantu, maka makna dasar secara tersurat akan melesap dan menyokong verba utama. Begitu juga pada kalimat 13 dan 14 .

Pada dasarnya verba yarimorai seperti kureru, ageru, morau apabaila berperan sebagai verba bantu dalam kalimat, maka makna kalimat akan mengandung makna rasa terima kasih dan rasa syukur dari penutur karena telah menerima suatu perbuatan kebaikan dari orang lain.

\section{2.わたしは 木村さんに 本を 貸して あげました。}

Watashi wa Kimura san ni hon o kashite agemashita.

Saya meminjamkan buku kepada Kimura.

\section{3.わたしは 山田さんに 病院の電話番号を 教えて もらいました。}

Watashi wa Yamada san ni byouin no denwa bangou o oshiete moraimashita. 64 | http://journal.unesa.ac.id/index.php/paramasastra 
Saya diberitahu nomor telpon rumah sakit oleh Yamada

\section{4. 母は わたしに セーターを 送って くねした。}

Haha wa watashi ni seetaa o okutte kuremashita.

Ibu mengirimkan sweater untuk saya.

Pada bab 41, diperkenalkan bentuk sopan dari verba yarimorai yang telah dibahas pada bab sebelumnya. Apabila orang yang menjadi benefaktor ataupun agentor adalah orang kedudukannya lebih tinggi daripada watashi/ saya seperti guru, kepala bagian, direktur dan sebagainya. Untuk menyatakan rasa hormat kepada pihak agentor, digunakan verba yarimorai dalam bentuk sopan seperti itadakimasu yang merupakan ragam sopan dari moraimasu, kudasaimasu yang merupakan bentuk sopan dari kuremasu dan sashi agemasu yang merupakan bentuk sopan dari agemasu.

\section{5. 私は ワット先生に 本をいただきました。}

Watashi waa Watto sensei ni hon o itadakimashita.

Saya diberi Pak Watt buku.

\section{6. わたしは 課長に 手紙の まちがいを 教えていただきました。}

Watashi wa kachou ni tegami no machigai o oshiete itadakimashita.

Saya diberitahu kepala divisi kesalahan pada surat saya.

\section{7. 部長の 奥さんは わたしに お茶を 教えて くださいました。}

Bucho no okusan wa watashi ni ocha o oshiete kudasaimashita.

Istri kepala bagian mengajarkan saya tata cara upacara minum teh. 
Untuk aktifitas yang dilakukan oleh pertama (sebagai agentor) kepada benefaktor yang kedudukannya lebih rendah (misalnya adik, anak, hewan peliharaan, tanaman), maka verba yarimorai yang digunakan adalah yarimasu (memberi) dengan bentuk verba bantu te yarimasu. Seperti pada contoh di kalimat (18), yang menjadi agentor adalah kata ganti orang pertama (watashi) dan sebagai pihak yang menerima aktifitas adalah anak laki-laki, maka verba bantu yang digunakan adalah te yarimasu, yang menyokong verba utama tsukurimasu (membuatkan).

Contoh

\section{8. わたしは 息子に 紙飛行機を 作って やりました。}

Watashi wa musuko ni kamihikouki o tsukutte yarimashita.

Saya membuatkan pesawat kertas untuk anak laki-laki saya.

\section{Kalimat kausatif (shieki/ 使役文)}

Ungkapan diatesis kausatif dinyatakan dengan mengimbuhkan verba bantu "seru" dan "saseru" pada verba. Bentuk kausatif merupakan bentuk verba dalam bahasa Jepang yang digunakan untuk menyatakan arti menyuruh atau menyebabkan seseorang melakukan suatu perbuatan (Sutedi, :83). Menurut Soepardjo (2012: 152), ungkapan kausatif ini menyebabkan terjadinya perubahan atau tindakan pada objek, dan dilihat baik dari segi makna atau dari segi bentuk selalu bersambung dengan bentuk transitif.

Ada beberapa verba yang tidak bisa dinyatakan dengan bentuk kausatif seperti aru (ada), iru (memerlukan), yomeru (dapat dibaca), karena pada verba tersebut tidak menyatakan aktifitas melainkan verba yang menyatakan keadaan.

Contoh

\section{9. 息子をイギリスへ 留学 させます。}

66 | http://journal.unesa.ac.id/index.php/paramasastra 
Parwati Hadi Noorsanti, Diatesis (TAl) dalam Bahasa Jepang...(hlm. 55 - 71)

Musuko o Igirisu e ryuugaku sasemasu.

Saya mengijinkan anak laki-laki saya untuk belajar di luar negeri.

\section{0. 娘に ピアノを 習わせます。}

Musume ni piano o narawasemasu.

Saya menyuruh anak untuk belajar piano

Pada kalimat 19 bentuk kausatif pada verba sasemasu yang berasal dari verba suru/ shimasu yang berarti melakukan, bentuk kausatif pada kalimat ini mengandung makna mengijinkan, sehingga anak laki-laki (musuko/息子) dapat melakukan kegiatan belajar di luar negeri (ryuugaku shimasu/留学します). Pada kalimat 20

\section{Diatesis Potensial (Kanoukei /可能形)}

Miyajima (2003: 277) menyebutnya dengan istilah kanoukoubun(可能構文), dengan pengertian bahwa diatesis potensial merupakan cara pengungkapan yang digunakan untuk menyebutkan dapat atau tidak dapat diwujudkan suatu aktifitas berdasarkan kemauan subjek pada kalimat transitif ( 能動主体が意志的な動作を行おうとするとき、その動作の実現が可能か不 可能かを述べるものである/Noudou shutai ga ishikitekina dousa o okonauto suru toki, sono dousa no jitsugen ga kanou ka fukanou ka o noberumono de aru)

Kata kerja potensial tidak menunjukkan perbuatan, melainkan keadaan. Objek kata kerja transitif biasanya ditunjukkan dengan kata bantu $o$, tetapi dalam 
kalimat kata kerja potensial, objek biasanya ditunjukkan dengan kata bantu $g a$, perhatikan kalimat 21 dan 22 berikut ini.

Contoh.

\section{1. 私は日本語を話します。}

Watashi wa Nihongo o hanashimasu.

Saya berbicara bahasa Jepang.

\section{2.わたしは日本語が話せます。}

Watashi wa Nihongo ga hanasemasu.

Saya dapat berbicara bahasa Jepang.

Secara arti, ada dua arti dari kanoubun, yaitu nouryoku kanou (能力可能) yang merupakan kemampuan dari usaha atau kemampuan dari subjek kalimat aktif dan Joukyou Kanou (状況可能) kemampuan dilihat dari keadaan, ada alasan di luar kemapuan subjek kalimat aktifnya.

1. Kemampuan karena Usaha Subjek (Nouryoku Kanou/能力可能)

\section{3. 僕はインド料理なんて作れない。}

Boku wa Indo ryouri nante tsukurenai.

Saya tidak bisa memasak masakan India.

\section{4. 英語で手紙なんて書けないよ。}

Eigo de tegami nante kanenai yo.

Saya tidak bisa menulis surat dalam bahasa Inggris. 


\section{5.わたしは 日本語が 少し話せます。}

Watashi wa nihongo ga sukoshi hanasemasu.

Saya bisa bahasa India sedikit.

Pada kalimat 23 'Indo ryouri nante tsukurenai' (tidak bisa memasak masakan India), disebabkan karena pembicara yang tidak menguasai cara pembuatan masakan India sehingga tidak bisa melakukan aktifitas memasak masakan India. Begitu juga dengan kalimat 24 dan 25, ketidakmamapuan untuk membaca surat dalam bahasa Inggris disebabkan oleh ketidakmampuan pembicara dalam menguasai bahasa Inggris sehingga ia juga tidak mampu untuk menulis surat dalam bahasa Inggris. Jadi kalimat 23, 24 dan 25, ketidakmampuan dalam melakukan sesuatu disebabkan oleh faktor kemampuan dari dalam diri pembicara sendiri.

\section{Kemampuan karena keadaan (Jokyou Kanourei/状況可能例)}

Pada kalimat potensial yang disebabkan oleh kedaan ini, kemampuan atau ketidakmampuan pembicara untuk melakukan sesuatu disebabkan oleh faktor dari luar diri pembicara yaitu keadaan, bukan karena faktor dari dalam diri pembicara. Pada kalimat 26, ketidakmampuan untuk memasak masakan India disebabkan oleh karena tidak bisa menemukan bahan-bahan untuk memasak masakan India di Jepang, bukan karena pembicara tidak memiliki kemampuan untuk memasak masakan India.

Contoh

\section{6. 日本では材料がそろわないから、インド料理が作れない。}

Nihon dewa zairyou ga sorowanaikara, Indo ryouri ga tsukurenai.

Karena tidak bisa mendapatkan bahan masakan di Jepang, saya tidak bisa memasak masakan India. 
Verba mimasu/ 見ますmemiliki bentuk potensial miraremasu/ 見られますyang artinya dapat melihat, dan bentuk potensial kikimasu/ 聞きますadalah kikemasu/ 聞けますyang artinya dapat mendengar. Kata kerja ini menunjukkan bahwa keinginan seseorang untuk melihat dan mendengar dapat direalisasaikan. Perhatikan contoh dari kalimat 27 dan 28 berikut ini.

\section{7. 新宿で今黒沢の映画が見られます。}

Shinjuku de ima Kurosawa no eiga ga miraremasu.

Sekarang, film karya Kurosawa dapat ditonton di Shinjuku.

\section{8. 電話で天気予報が聞けます。}

Denwa de tenkiyohou ga kikemasu.

Dengan telepon kita dapat mendengar prakiraan cuaca.

Tetapi kata miemasu見えます dan kikoemasu 聞こえますtidak berhubungan dengan keinginan seseorang, melainkan menunjukkan suatu gambaran yang dapat ditangkap oleh mata atau telinga kita. Pada kalimat 29 dan 30, objek kalimat menjadi subjek dan ditunjukkan dengan kata bantu $g a$.

\section{9. 新幹線から富士山が見えます。}

Shinkansen kara Fujisan ga miemasu.

Dari shinkansen kelihatan gunung Fuji.

\section{0. ラジオの音が聞こえます。}

Rajio no oto ga kikoemasu.

Terdengar suara radio. 
Parwati Hadi Noorsanti, Diatesis (TAl) dalam Bahasa Jepang...(hlm. 55 - 71)

\section{SIMPULAN}

Bentuk diatesis dalam bahasa Jepang diantaranya terdiri dari bentuk pasif (ukemibun/受身文), bentuk kausatif (shiekibun/使役文), Ungkapan memberi dan menerima (juju hyougen/授受表現), dan bentuk potensial (kanoubun/可能文). Dengan hanya memahami struktur kalimat saja tidak cukup untuk dapat pemahaman yang mendalam terhadap kalimat diatesis bahasa Jepang ini, pembelajar juga harus benar-benar memperhatikan hubungan antar partisipan atau kedudukan masing-masing partisipan dalam dalam kalimat. Salah satu hal yang dapat membantu pembelajar dalam memahami kalimat dalam diatesis ini adalah memahami fungsi kata bantu atau partikel (joshi/ 助詞) dalam kalimat, sehingga pembelajar dapat mengetahui kedudukan masing-masing partisipan dalam kalimat.

\section{DAFTAR RUJUKAN}

Chaer, Abdul. 2007. Linguistik Umum. Jakarta: Rineka Cipta

Kridaklasana, Harimurti. 2001. Kamus Linguistik. Jakarta: Gramedia Pustaka Utama

Shirakawa, Hiroyuki. 2002. Chuиjokyuи wo Oshieru Hito no tame no Nihongo no Bunpou Handobukku. Tokyo: 3A-Network

Soepardjo, Djodjok. 2012. Linguistik Jepang. Surabaya: Penerbit Bintang

Sutedi, Dedi. 2008. Dasar-dasar Linguistik Bahasa Jepang. Bandung: Humaniora Tsujimura, Natsuko. 2000. An Introduction to Japanese Linguistics. New Jersey: Blackwell Publishing

Miyajima, Tatsuo. 2003. Gendai Nihongo Bunpou. Tokyo: Kurushio Shuppan 